\title{
The Optimization of Teacher Competencies to Improve Education Service Using Teacher Collaborations Model
}

\author{
Rokhmaniyah $^{1}$ \\ ${ }^{1}$ Elementary School Teachers Training Study Program, Faculty of Teacher Training \\ and Education Science, Universitas Sebelas Maret (UNS)
}

\begin{abstract}
This article describes the results of research aims to: (1) explain the steps of applying teacher collaboration model to improve education service in elementary school (2) to optimize teacher professional competence through teacher collaboration model. This research is a action research. The action is carried out for 2 cycles. Each cycle consists of four stages, namely: planning, action, obeservasi, and reflection. Research subjects were teachers from State Elementary School 5 Kutosari, Wergonayan Mirit Kebumen, and a teacher from Tambakprogaten Elementary School Klirong Kebumen. The technique of data collection was observation, interview, and documentation study. The data were analyzed qualitatively in reference to Miles and Huberman (1984)) with steps: (1) data reduction, (2) data presentation, and (3) drawing conclusions and data verification. To keep the validity of data, I used triangulation, a technique to assure the validity of data produced by observation, interview, and documents. Result of this study shows that teacher competencies for learning management based on curriculum of 2013 increase $9.43 \%$ from the category of good (76.60) become very good (86.03). To conclude, the implementation of teacher collaborations model can optimize teacher competencies to improve education services in elementary schools of Kebumen district.
\end{abstract}

Keywords: teacher collaborations; competencies; education service

\section{INTRODUCTION}

High quality education has been the desire of Indonesian people, and good human resources is the main factor in achieving this desire. Teachers, in this case, play the most important role in high quality education. Teachers must have the appropriate ability, desire and readiness to work and improve. Accuracy, the diversity of this profession makes serious demands to the process of specialists training (Zakirova , 2016). Therefore, the organization of teacher training process should ensure not only mastery of a set of special knowledge and skills, but also the conditions for further development of appropriate methods of activity (Salyakhova \& Valeeva, 2015).

This article shows that the quality of education in all education institutions in Kebumen district has not met high academic standards. According to the documentation of national examination result in 2013, some education institutions 
cannot reach higher grade than the average grade of national examination. One of the supporting factors is the uneven quality of teachers in Kebumen district (The strategic plan of the Kebumen District Education, Youth and Sports Officeun, 2014). In solving this gap and improving teacher competencies, I believe teacher collaborations model in teaching activity is important. High quality teachers are expected to improve education service. A competence is best described as 'a complex combination of knowledge, skills, understanding, values, attitudes and desire which lead to effective, embodied human action in the world, in a particular domain' (Deakin, 2008). Competence it empowers the teacher to act professionally and appropriately in a situation (Koster \& Dangerink, 2008).

Competency is an entity attached to an individual and the combination of knowledge, attitude, and skill. Paasoc\&Korento (2010) stated that "a competent teacher's work can be seen in on-the-job learning in that students are more prepared. Competence in supervision of final projects and on-the-job learning is at a high level".

Teacher collaboration is meant to work together to improve learning. Collaborative relationships should not be in school, but can also be done on a crossschool basis. The most common form of teacher collaboration is between teachers within one school or department; however, in England networks do exist that involve teachers from different schools (cross- school) (Rempe-Gillen,2017, p.1-13). The Ministry of Education and Culture of the Republic of Indonesia (2014) has conducted teacher collaborations model. It consists of (1) Initial verification to determine school eligibility and qualifications; (2) first technical guidance; (3) On Job Training (OJT); (4) second technical guidance; (5) In House Training (IHT); (6) mentoring and monitoring; and (7) dissemination. This model of collaborations is commonly used in the field of education to improve the quality of education in the aspect of human resources (SDM), namely the improvement of teacher competence that is by way of collaboration between teachers in high-quality school with teachers in poor-quality school. Training workshops to enhance mutual understanding of others' professional roles have met with success (VanWinkle et al., 2012). Related to group learning, many researchers see the environment and social structures as key to the cognitive activities associated with collaboration (Dillenbourg, 1999). Furthermore, it is said that a prominent finding of existing research into teacher learning is that professional communities are effective 'agents' for enhancing professional learning and sustained professional development (Stoll, Bolam, McMahon, Wallace, \& Thomas, 2006; Webster-Wright, 2009).

Schools with strong teacher communities seem to have higher student achievement (Bryk, Sebring, Allensworth, Luppescu, \& Easton, 2010; Horn \& Kane, 2015. Service is an action of serving, preparing, organizing, and solving someone or a group of people's needs (Sianipar, 2000). A good education service will motivate students to be comfortable with school. A good service gives satisfaction to consumers. In this case, the consumers are students.

So, this research procedure follow the procedure of teacher collaborations model which has been done by the Ministry of Education and Culture of Indonesia with little change by the author.: (1) preparation; (2) determining collaborations structure; (3) fist technical guidance; (4) implementation of On the Job Training; (5) second technical guidance; (6) implementation of In House Training; and (7) dissemination of In House Training. 
This study aims to: (1) explain the steps of applying teacher collaboration model to improve education service in elementary school (2) to optimize teacher professional competence through teacher collaboration model.

\section{RESEARCH METHODS}

This research is a action research. Action research aims to contribute both to the practical concern of people in an immediate problematic situation and to the goals of social science by joint collaboration within a mutually acceptable ethical framework (Hopkins, 1993). This action study follows the model proposed by Kemmis and McTaggart (1988). Kemmis and McTaggart (1988) developed a concept for action research. They proposed a spiral model comprising four steps: planning, acting, observing and reflecting. This is done to answer what and how the implementation of teacher collaboration model can optimize teacher competence to improve education service. Research subjects were teachers from State Elementary School 5 Kutosari, Wergonayan Mirit Kebumen, and a teacher from Tambakprogaten Elementary School Klirong Kebumen. These schools meet the criteria as research subjects.

The action is carried out for 2 cycles. Each cycle consists of four stages, namely: planning, action, obeservation, and reflection. The focus of action for each cycle is the same: lesson plan preparation process, learning process implementation, ending the learning process. The difference is in the subjects being taught. The core of this action research is to improve the management of learning through a scientific approach.

The focus on teacher collaborations in numerous countries differs because of cultural differences (So, Sin, \& Son, 2010). The technique of data collection was observation, interview, and documentation study. Observation is used to obtain data learning management. Interviews were used to extract data on teachers relating to the meaningful benefits of collaborative learning improvement processes. Meanwhile, the documentation is used to perform document observations Curriculum and learning tools. The data were analyzed qualitatively in reference to Miles and Huberman (1984)) with steps: (1) data reduction, (2) data presentation, and (3) drawing conclusions and data verification. To keep the validity of data, I used triangulation, a technique to assure the validity of data produced by observation, interview, and documents.

\section{RESULTS AND DISCUSSION}

\section{The application of teacher collaborations model in optimizing teacher competencies}

\section{PREPARATION}

Stakeholders and I conducted Preparation. The result of Preparation shows that teacher collaborations model is used to improve teacher competencies in elementary schools in Kebumen district in the aspect of learning management with a scientific 
approach.

\section{DETERMINING COLLABORATIONS STRUCTURE}

At this stage the researcher looks at the collaboration structure. The first collaborators were determined by grade 1,2, 3, and 4 teachers from primary school with accreditation status A and have practiced scientific approach, namely Sekolah Dasar Negeri 1 Kotosari Kebumen.

\section{FIRST TECHNICAL GUIDANCE}

First technical guidance is conducted to obtain a similar perception related to learning tools with scientific approach. Technical guidance is done by collaborators and researchers. In addition, observations were also made on the document of learning devices in public elementary schools where collaborators on duty (State Elementary School 1 Kutosari Kebumen) by teachers from three schools (research subjects)

\section{IMPLEMENTATION OF ON THE JOB TRAINING}

At this stage of the job training, teachers from three schools (research subjects) observed instructional management with a scientific approach in elementary school where collaborators on duty, the state primary school 1 Kutosari Kebumen.

\section{SECOND TECHNICAL GUIDANCE}

Activities on second technical guidance are the preparation of learning tools with a scientific approach by teachers from three schools (research subjects) with guided by collaborators.

\section{IMPLEMENTATION OF IN HOUSE TRAINING}

The in-house training stage is an important stage, namely teachers in three schools (research subjects) practicing learning management with a scientific approach. Collaborators and researchers make observations on learning tools, learning processes, and how to open and close learning. The observation of 12 teachers from three schools was scheduled starting from the state elementary school 5 Kutosari Kebumen, then to the Tambakprogaten elementary school of Klirong Kebumen, and finally at Wergonayan Mirit Kebumen state elementary school.

\section{DISSEMINATION OF IN HOUSE TRAINING}

Dissemination activities are activities aimed at announcing / disseminating the results of learning management practices ranging from the preparation of learning tools, learning processes, and activities to open and close / evaluate learning. Dissemination is done by research subjects and collaborators. The teachers (research 
subjects) convey the obstacles and solutions that are done related to the learning management that has been practiced. Meanwhile, the collaborators convey the results of observations on learning management. Next, they asked questions and answers. The result of dissemination is used as a basis for reflection of action.

\section{Optimize Teacher Professional Competence through Teacher Collaboration Model}

\section{RESULTS RESEARCH OF CYCLE I}

Based on the observation of learning device document, observation of learning process, and observation on how to close the learning can be described as follows. Observation result show that from the 12 teachers, 8 teachers received a good evaluation and 4 teachers got enough assessment. Assessment is obtained from the average score of observation results of the three elements above. More specifically, consider Table 1. below.

TABLE I. OBSERVATION RESULTS OF CYCLE 1

\begin{tabular}{|c|c|c|c|c|c|c|c|}
\hline \multirow[t]{2}{*}{ NUMBER } & \multirow[t]{2}{*}{ NAME } & \multicolumn{3}{|c|}{ SCORE } & \multirow[t]{2}{*}{ SUM } & \multirow[t]{2}{*}{ SCORE } & \multirow[t]{2}{*}{ CONVERSION } \\
\hline & & A & B & $\mathrm{C}$ & & & \\
\hline 1. & $1 \mathrm{KS}$ & 44 & 111 & 12 & 167 & 80.28 & good \\
\hline 2. & $2 \mathrm{KS}$ & 43 & 113 & 10 & 166 & 79.80 & good \\
\hline 3. & $4 \mathrm{KS}$ & 37 & 120 & 11 & 168 & 80.76 & good \\
\hline 4. & $5 \mathrm{KS}$ & 44 & 109 & 13 & 166 & 79.81 & good \\
\hline 5. & $1 \mathrm{~W}$ & 43 & 115 & 11 & 169 & 81.25 & good \\
\hline 6. & $2 \mathrm{~W}$ & 42 & 99 & 12 & 153 & 73.56 & enough \\
\hline 7. & $4 \mathrm{~W}$ & 46 & 107 & 12 & 165 & 79.33 & good \\
\hline 8. & $5 \mathrm{~W}$ & 44 & 97 & 12 & 153 & 73.56 & Good \\
\hline 9. & $1 \mathrm{~T}$ & 36 & 108 & 12 & 156 & 75.00 & Enough \\
\hline 10. & $2 \mathrm{~T}$ & 44 & 96 & 10 & 150 & 76.92 & Good \\
\hline 11. & $4 \mathrm{~T}$ & 43 & 88 & 12 & 143 & 68.75 & enough \\
\hline 12. & $5 \mathrm{~T}$ & 45 & 91 & 10 & 146 & 70.19 & enough \\
\hline
\end{tabular}

Note : A : Lesson plan preparation process

B : Learning process implementation

$\mathrm{C}$ : Ending the learning process

Lesson plan preparation process learning component (column A) includes indicators: (1) identity writing; (2) writing basic competencies, core competencies, and themes; (3) formulation of indicators in accordance with basic competence; (4) formulation of learning objectives in accordance with indicators and competencies; (5) selection of teaching materials in accordance with the indicators; (6) selection of 
learning resources; (7) selection of learning media; (8) approaches, methods, models; (9) preliminary activities; (10) core learning scenarios; (11) assessment; and (12) close learning.

Learning process implementation components (column B) include elements of preliminary activities and core activities. Elements of preliminary activities include aspects of the learning apperception, delivery of competence and activity plan. Aspects of learning apperception include indicators: (1) linking current learning materials with previous learners' experiences or learning, (2) making challenging statements, (3) conveying the benefits of learning materials, and (4) demonstrating something related to the theme. Aspects of the delivery of competencies and activity plans include indicators: (1) conveying the ability to be achieved by learners and (2) submitting activities for example, individual, group work, and observation.

Elements of core activities include aspects of mastery of learning materials, application of learning strategies that educate, application of scientific approach, utilization of learning resources / media in learning, involvement of learners in learning, and aspects of the correct and appropriate language usage in learning. (2) the ability to link the material with other relevant knowledge, the development of science and technology, and the real life, (3) present the discussion of the learning materials appropriately, and (4) the ability to match the material with the objectives of learning, presents the material systematically (easily difficult, from concrete to abstract).

Aspects of the implementation of educational strategies that include educational indicators: (1) implement learning in accordance with the competencies to be achieved; (2) facilitating activities containing exploration, elaboration, and confirmation components; (3) conduct a coherent learning; (4) mastering the class; (5) implementing learning that is of a constitutional nature; (6) implementing learning that enables the growth of positive habits (nurturant effect); and 7) implementing learning in accordance with the planned time allocation.

Aspects of applying a scientific approach include: (1) asking questions why and how, (2) provoking learners to ask, (3) facilitating learners to try, (4) facilitating learners to observe, (5) observing learners to analyze , (6) giving learners questions for reasoning (logical and systematic thinking processes), (7) Presenting learners' activities to communicate.

Aspects of the use of learning resources / media in learning include: (1) showing skills in the use of learning resources, (2) showing skills in the use of learning media, (3) generating interesting messages, (4) showing conducive interpersonal relationships, and indicators (5) Grow the joy or enthusiasm of learners in learning.

Aspects of the involvement of learners in learning include: (1) fostering students' participation through interaction of teachers, learners, learning resources; (2) respond positively to the participant's partition; (3) addressing open attitude toward learners' response in learning; (4) showing a conducive interpersonal relationship; and (5) foster the cheerfulness or enthusiasm of learners in learning. Aspects of correct and proper use of language in learning include indicators: (1) using spoken language clearly and fluently and (2) using good and correct written language.

The ending the learning process component (column C) consists of indicators: (1) reflecting or making a summary by involving learners, (2) providing oral or written tests, (3) collecting work as a portfolio, and (4) follow-up by providing direction for enrichment activities and tasks.ng spoken language clearly 
and fluently and (2) using good and correct written language.

Thus, scores on each indicator are obtained on a scale of 0-4. Maximum score is 4 times the number of indicators. Meanwhile, the lowest score is 0 . The scores are obtained as a result of observation.

\section{RESULTS RESEARCH OF CYCLE II}

In cycle II, there is an increasing of teacher's competencies in implementing learning management. The improvement is shown in the scores on three components: lesson plan preparation process, learning process implementation, and opening and ending the learning process. Table 2 is the result of observation on learning management, shows a significant increase in the early verification before the implementation of teacher collaborations model. The table also reveals almost perfect score of 90,38 and 91,10. It means that some teacher's ability to prepare lesson plan is near-perfect. Some teachers also have average score higher than 120 in learning implementation. In closing the lesson, there was one teacher can close the learning process very well and get score of 16. Some teachers are also near-perfect. Collaborating is considered a feasible approach to changing teachers' traditional teaching philosophy. Teachers collaborating on a project such as a lesson can exchange teaching ideas and experiences, discuss teaching practices, provide each other with feedback, and participate in further changes to teachers' cognition and/or behavior (Meirink, Meijer, \& Verloop, 2007). Currently, teachers are often expected to improve their teaching as well as to enhance student learning through mutual experience-sharing and collective learning in school teaching teams. However, teachers struggle with the move from isolation to collaboration and the tension between autonomy and collaboration (Puchnera, \& Taylor, 2006). Notice the following Table II. 
TABLE II. RESULTS OBSERVATION OF LEARNING MANAGEMENT THROUGH TEACHER COLLABORATIONS MODEL ON CYCLE II

\begin{tabular}{|c|c|c|c|c|c|c|c|}
\hline \multirow[t]{2}{*}{ Number } & \multirow[t]{2}{*}{ Name } & \multicolumn{3}{|c|}{ Score } & \multirow[t]{2}{*}{ Sum } & \multirow[t]{2}{*}{ Score } & \multirow[t]{2}{*}{ Conversion } \\
\hline & & A & B & $\mathrm{C}$ & & & \\
\hline 1. & $1 \mathrm{KS}$ & 45 & 135 & 13 & 191 & 91.10 & Very good \\
\hline 2. & $2 \mathrm{KS}$ & 44 & 127 & 13 & 184 & 88.46 & Very good \\
\hline 3. & $4 \mathrm{KS}$ & 45 & 120 & 15 & 180 & 86.53 & Very good \\
\hline 4. & $5 \mathrm{KS}$ & 44 & 114 & 15 & 168 & 80.76 & good \\
\hline 5. & $1 \mathrm{~W}$ & 46 & 130 & 13 & 188 & 90.38 & Very good \\
\hline 6. & $2 \mathrm{~W}$ & 42 & 126 & 13 & 181 & 87.02 & Very good \\
\hline 7. & $4 \mathrm{~W}$ & 46 & 122 & 13 & 181 & 87.02 & Very good \\
\hline 8. & $5 \mathrm{~W}$ & 44 & 128 & 15 & 187 & 89.90 & Very good \\
\hline 9. & $1 \mathrm{~T}$ & 36 & 128 & 14 & 180 & 86.83 & Very good \\
\hline 10. & $2 \mathrm{~T}$ & 44 & 109 & 11 & 164 & 78.8 & good \\
\hline 11. & $4 \mathrm{~T}$ & 43 & 124 & 16 & 183 & 87.98 & Very good \\
\hline 12. & $5 \mathrm{~T}$ & 45 & 106 & 11 & 162 & 77.84 & good \\
\hline
\end{tabular}

Note: A : Lesson plan preparation process

B : Learning process implementation

$\mathrm{C}$ : Opening and ending the learning process

Teacher Collaborations is very effective for improving teacher competence in managing learning. Teaching teams that collaborate between schools can provide teachers with opportunities to exchange experiences in managing learning. However, there are still teachers who have not been interested in collaborating in the teaching team. He still loves to work alone in his class with time reasons. This is in line with opinion Edmunds (2009); Hughes \& Kritsonis (2006); Nompula (2012), even though schools have organized a teaching team for their teachers, some teachers still preferred to work alone in their classrooms

\section{INTERVIEW RESULTS}

The result of interview shows that there is a changing mindset in poor-quality schools after partnering with high-quality school. Professional development focused on collaborative practice should include role understanding, collaborative decisionmaking, conflict and change management, care processes, and continuous quality improvement (Newton, Wood, \& Nasmith, 2012). Poor-quality schools now concern more on critical thinking and being productive. Learning management is also shifting from administration-based to students ability-based to achieve main competencies that is spirituality, social, knowledge, and skill. Teaching team structures instead of professional learning community have been implemented as part of the school improvements to promote a collaborative mode of teaching and comprehensive education for students in many countries around the world (Liu \& Tsai, 2017, p.159). "Working with community partners also increases the likelihood that students will work on projects that are of real value to the community and that they will develop real world skills" (Powers, 2004: 21). 


\section{CONCLUSION}

According to the result of the research, it can be concluded that the implementation of teacher collaborations model consists of several steps. They are (1) Preparation; (2) collaborations structure determination; (3) first technical guidance; (4) implementation of OJT; (5) second technical guidance; (6) implementation of IHT, mentoring, and monitoring; (7) dissemination of IHT result report by high-quality schools and poor-quality schools; (8) data analysis after the implementation of teacher collaborations model; (9) processing data resulted from the implementation of teacher collaborations model; and (10) reporting research results in the form of conclusion and suggestion for following up the result. The research shows that teacher collaborations model is able to improve teacher competencies $9.43 \%$ from good category (76.60) to be very good (86.03) in the evaluation of 2013 curriculum-based learning management evaluation. Optimizing teacher competencies through teacher collaborations model in learning management have a positive impact in the improvement of teacher competencies. This improvement will be followed by the improvement in education service satisfaction.

\section{ACKNOWLEDGMENTS}

The work is performed according to Research Institutions and Community Service of Universitas Negeri Sebelas Maret.

\section{REFERENCES}

[1] Zakirova, R.R. (2016). The Structure of Elementary School Teachers' Professional Competence.International Journal of Environmental \& Science Education,

[2] Salyakhova, G. I. \& Valeeva, R. A. (2015). Pedagogical Stimulation of University Students' Social Competence Development by Means of Interdisciplinary Integration. Review of European Studies, 7(5),186-192.

[3] Koster, B. and Dengerink, J. J. (2008). Professional standards for teacher educators: How to deal with complexity, ownership and function. Experiences from the Netherlands. EuropeanJournal of Teacher Education, 31:2, 135-149.

[4] Paaso, A., \& Korento, K. (2010). The competent teacher 2010-2020. The competences of teaching staff in upper secondary vocational education and training.Final report. Tampere: Juvenes Print.

[5] Rempe-Gillen, E. (2017). Elementary school teacher experiences in cross-phase professional development collaborations. Professional Development in Education Journal, p.1-13.http://www.tandfonline.com/doi/full/10.1080/19415257.2017.1328455? scroll=top\&needAccess=true. Published online: 28 Jun 2017

[6] Ministry of Education. (2014). Pertukaran Pendidikdan Tenaga Kependidikan SMA Jakarta:Ministry of Education.

[7] VanWinkle, L. J., Bjork, B. C., Chandar, N., Cornell, S., Fjortoft, N., \& Green, J. M. (2012). Interprofessional workshop to improve mutual understanding between pharmacy and medical students [computer file]. American Journal of Pharmaceutical Education, 76(8).

[8] Dillenbourg, P. (1999). What do you mean by ‘collaborative learning?'. In P. Dillenbourg (Ed.), Collaborative-learning: Cognitive and computational approaches (pp. 1e19). Oxford: Elsevier.

[9] Stoll, L., Bolam, R., McMahon, A., Wallace, M., \& Thomas, S. (2006).Professional Learning Communities: A review of the Literature. Journal of Educational Change, 7(4), 221e258. 
[10] Webster-Wright, A. (2009). Reframing Professional Development through Understanding Authentic Professional Learning. Review of Educational Research, 79(2), $702 \mathrm{e} 739$.

[11] Bryk, A. S., Sebring, P. B., Allensworth, E., Luppescu, S., \& Easton, J. Q. (2010). Organizing schools for improvement: Lessons from Chicago. Chicago, IL: University of Chicago Press

[12] Horn, I. S., \& Kane, B. D. (2015). Opportunities for professional learning in mathematics teacher workgroup conversations: Relationships to instructional. expertise. The Journal of the Learning Sciences, 24(3), 1e46.

[13] Sianipar, J. P. G., ( 2000). Manajemen Pelayanan Masyarakat, Lembaga Administrasi Negara, Jakarta.

[14] Hopkins, D. (1993). A Teacher Guide to Classroom. Philadelphia: Open Univercity Press. Hospon, R., Miller, P. \& Lovelace, Timple S. (2016). Leadership and Policy inSchools; University-School-Community Collaborations as Vehiclef or Leadership,Service, and Change:A Critical Brokerage Perspective. Journalhomepage:http://www.tandfonline.com/loi/nlps20.

[15] Kemmis, Mc . \& Taggart, R. (1988). The action research planner. Australia, Victoria: Deakin University

[16] So, K., Sin, J., \& Son, W. (2010). A contrastive study of classroom teaching in Korea and Japan: a case study on reforming schools into learning communities. Asia Pacific Education Review, 11, 273-283. https://doi.org/10.1007/s12564-010-9075-3.

[17] Miles, M.B. \& Huberman, M.A. (1984). Qualitative Data Analysis. London: Sage Publication

[18] Meirink, J. A., Meijer, P. C., \& Verloop, N. (2007). A closer look at teachers' individual learning in collaborative settings. Teachers and Teaching: Theory and Practice, 13(2), 145-164. https://doi.org/10.1080/13540600601152496

[19] Puchner, L. D. \& Taylor, A. R. (2006). Lesson study, collaboration and teacher efficacy: Stories from two school-based math lesson study groups. Teaching and Teacher Education, 22,922-934. https://doi.org/10.1016/j.tate.2006.04.011

[20] Edmunds, N. (2009). Improving teacher morale with team-building. Ann Arbor, MI: East Tenesse State University and Proquest LLC.

[21] Newton, C., Wood, V., \& Nasmith, L. (2012). Building capacity for interprofessional practice.The Clinical Teacher, 9, 94-98.

[22] Liu, S. H., \& Tsai, H. C. (2017). Teachers' Experiences of Collaborating in School Teaching Teams. Asian Social Science, 13(2), 159.

[23] Powers, Amy L. (2004). An Evaluation of Four Place-Based Education Programs.SUMMER 2004,VOL. 35,NO. 4.http://ecosensing.org/wp- content/uploads/2015/10/Powers-JEE-article.pdf. 